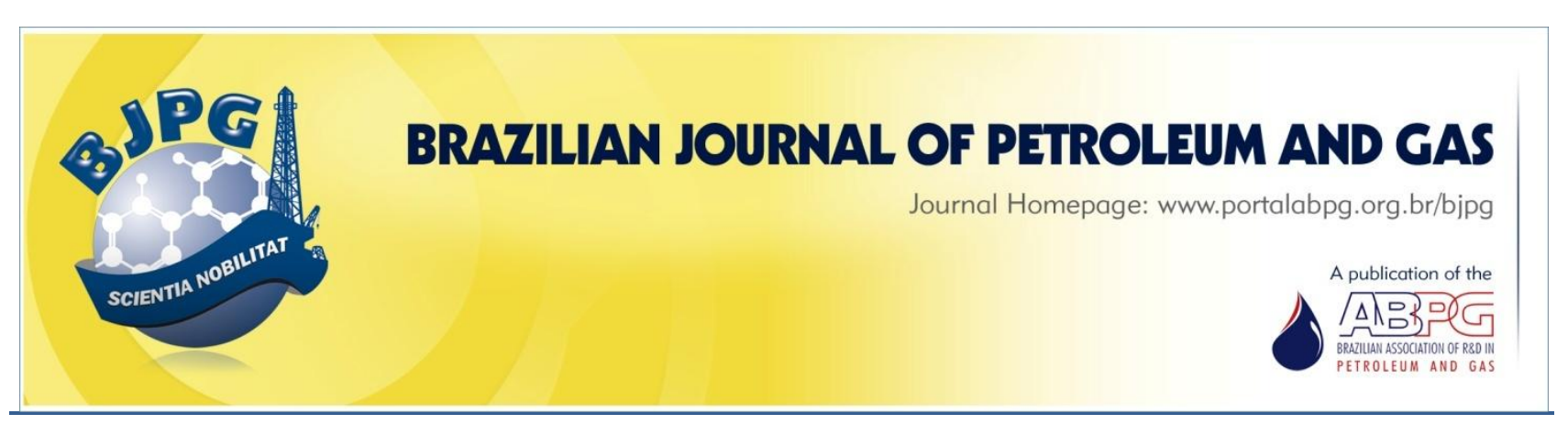

\title{
NaY ZEOLITES IMPREGNATED WITH NICKEL FOR ADSORPTION OF SULFUR COMPOUNDS FROM FUEL MODEL MIXTURE
}

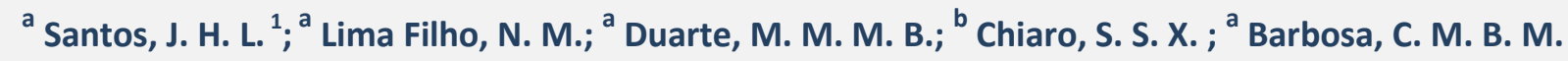 \\ ${ }^{a}$ Chemical Engineering Department, Federal University of Pernambuco, Recife, Brazil \\ ${ }^{b}$ Leopoldo Miguez de Mello Research Center (CENPES)/PETROBRAS S.A.
}

\begin{abstract}
This work aims to develop new adsorbents for the removal of sulfur from fuels to meet the new regulations for vehicle emissions. A study has been carried out to remove sulfur from the propanethiol/cyclohexene model mixture, at ambient conditions, using $\mathrm{Ni} / \mathrm{NaY}$ as adsorbent. The material was characterized by EAA, DRX, BET, and TGA. Propanethiol adsorption in cyclohexene was assessed by kinetics in a finite bath system, which was compared with the commercial adsorbent Selexsorb. The sulfur content was analyzed by gas chromatography. Results showed the incorporation of nickel in the structure of $\mathrm{Y}$ zeolite with retention of crystallinity and a higher adsorption capacity for $\mathrm{Ni} / \mathrm{NaY}$.
\end{abstract}

\section{KEYWORDS}

adsorption; fuel; sulfur; zeolites

\footnotetext{
${ }^{1}$ To whom all correspondence should be addressed.

Address: Federal University of Pernambuco, Chemical Engineering Department, Rua Prof. Artur de Sá, s/n, Cidade Universitária, Recife - Brazil, Zip code: 50740-521

Telephone / Fax: +55 81 2126-7291/ +55 81 2126-8238| E-mail: Jeanheliton@yahoo.com.br doi:10.5419/bjpg2013-0010
} 


\section{INTRODUCTION}

Among various air pollutants, sulfur dioxide $\mathrm{SO}_{2}$ has received special attention from government agencies due to the severity of its negative effects, on human and animal health and even on vegetation. The analysis of the sulfur content in automotive fuels (petrol and diesel) is an important parameter due to its contribution to the formation of acid rain. This acidic precipitation is caused by the emissions of $\mathrm{SO}_{2} / \mathrm{SO}_{3}$, material particulate, apart from poisoning the catalytic converter for exhaust emission treatment (Bhandari et al., 2006).

Nowadays, there is a worldwide trend to regulate the amount of sulfur in gasoline and diesel. The accepted levels of sulfur range between 10 and $50 \mathrm{mgL}^{-1}$ (Song, 2003). The European legislation, enacted in 2009, restricts sulfur levels to less than $10 \mathrm{mgL}^{-1}$ for both fuels (Li et al., 2007).

In 2001, technicians of environmental regulatory agencies and companies in the Brazilian petrochemical industry, such as PETROBRAS, prepared a document that established guidelines to mitigate the content of sulfur in Brazilian fuels. The goal of the document was to reduce the sulfur content in automotive fuels in Brazil, accepting limits up to $1000 \mathrm{mgL}^{-1}$ for petrol by 2006 . The limit reduction was planned to reach the $400 \mathrm{mgL}^{-1}$ mark until 2007, and 50 $\mathrm{mgL}^{-1}$ until 2009 (Dauzacker and Palombo, 2003).

Refineries are constantly looking for ways to reduce the percentage of sulfur in fuels in view of the environmental regulations. They are also seeking as ways to improve the standards to be used for detection and quantification of that element. The main process to reduce sulfur levels in hydrocarbon fractions in the petroleum refining industry is the catalytic hydrodesulfurization (HDS). The process of hydrodesulfurization is allocated in the processes of hydrotreating (HDT), which are generally expensive. The high cost associated with these processes are due to the use sophisticated catalysts of cobalt and molybdenum, the need for high temperatures, and a high consumption of hydrogen between 20-60atm pressure (Song and Ma, 2003). This is certainly an effective process for reducing sulfur compounds, although it has been proven that it acts primarily on the thiols (mercaptans) and sulfides, but is less efficient for the removal of thiophene compounds (Takahashi et al., 2002).

Numerous desulfurization processes have been developed for the removal of sulfur compounds and, among these, the adsorption process has stood. The adsorption is based on the selectivity of the adsorbents to capture contaminants organosulfur as mercaptans, thiophenes, and benzotiophenes, which are present in the industrial flows. The results on environmental temperature and pressure, without the need to use hydrogen and with the advantage of not compromising the octane level of gasoline, show very low levels of sulfur (Breysse et al., 2003; Noda et al., 2008). The use of adsorbents for the selective removal of sulfur contaminants from different refinery streams is a promising approach for producing clean fuels that meet the most stringent specifications (Santos et al., 2012).

The application of zeolites in the industry of pollution control is growing in importance, not only due to the low cost of certain applications, but also because of its zeolitic structure which is able to adsorb thiols and organic sulfides compounds. Recent developments show improvement on the knowledge of zeolites' properties and characteristics. However, the trend in the area of new materials is to encompass, the development of new types of zeolites, as well as chemical modifications in existing zeolites (Breck, 1984; Li et al., 2009).

King et al. (2000) studied the adsorption capacity of a ZSM-5 system in a fixed-bed system with thiophene, methyl and dimethylthiophene in the presence of toluene and p-xylene. Results showed that thiophene was preferentially adsorbed. They justified such behavior by the fact that the pore size of ZSM-5, between 5.2 and $5.6 \AA$, hindered the adsorption of organic sulfur compounds with more than one aromatic ring.

Lin et al. (2011) studied the capacity of adsorption of the $\mathrm{Y}$ zeolite ( $\mathrm{AgY}$ and $\mathrm{CeY}$ ) in a system of continuous stream bed for sulfur removal. Breakthrough experiments had shown that the capacity of adsorption of sulfur increased for the studied adsorbents as follows: $\mathrm{CeY}>\mathrm{AgY}>$ $\mathrm{NaY}$. The isotherms of adsorption and the snapshots of density of distribution for simulation in computer confirmed the competitive adsorption between thiophene and $\mathrm{n}$-heptan. 
Velu et al. (2003) reported that transition metal ion (such as $\mathrm{Cu}, \mathrm{Ni}, \mathrm{Zn}, \mathrm{Pd}$, and $\mathrm{Ce}$ ) that exchanged with $\mathrm{NH}_{4}-\mathrm{Y}$ zeolite showed selective adsorption for sulfur in a sample mixture of jet fuel. This study suggests that transition metal ions have a strong affinity for the adsorption of organic sulfur compounds.

Bhandari et al. (2006) studied the removal of sulfur from a diesel sample mixture comprising all major refractory sulfur compounds such as benzothiophene, dibenzothiophene, and 4,6dimethyl dibenzothiophene. The experiment used adsorption at room temperature with Y-zeolites exchanged with metal ions. High capacities for sulfur removal were observed for the Ni-Y $(\sim 42 \mathrm{mg}$ $\left.\mathrm{g}^{-1}\right)$ and the $\mathrm{Cu}-\mathrm{Y}\left(\sim 31 \mathrm{mg} \mathrm{g}^{-1}\right)$ zeolites.

Li et al. (2009) evaluated the removal capacity of thiophene from a sample mixture of fuels using zeolite ( $\mathrm{NaY}$ ) modified with copper ( $\mathrm{CuNaY}$ ), prepared using microwave radiation in the ion exchange step, obtaining a removal capacity of $1.22 \mathrm{mmol} \mathrm{g}^{-1}$.

Oliveira et al. (2009) evaluated the capacity of adsorption of thiophene and toluene by $\mathrm{NaY}$ zeolite exchanged with transition metals ( $5 \mathrm{wt} . \% \mathrm{Ni}, \mathrm{Zn}$, and $\mathrm{Ag}$ ). The adsorption capacity for both the samples studied presented the following order: AgY> NiY> ZnY> NaY. These results show the importance of inserting metal transitions in the zeolitic structure to increase the adsorption of both aromatic and organic sulfur compounds in liquid mixtures.

Santos et al. (2012) studied the incorporation of cerium, nickel, and molybdenum oxides on samples of commercial silica-alumina for adsorption of sulfur compounds from fuel. The experiment showed an increase in total adsorption capacity for sulfur. Dispersed silver oxides on supports as $\mathrm{TiO}_{2}$, c- $-\mathrm{Al}_{2} \mathrm{O}_{3}$, and $\mathrm{SiO}_{2}$ were considered effective desulfurizing agents for refined fuels at ambient conditions (Nair and Tatarchuk, 2010).

To expand the studies on the removal of sulfur compounds in fuels, this paper aims to identify adsorption properties of nickel impregnated in $Y$ zeolite for sulfur removal in a propanethiol/cyclohexene mixture model that represents the propanethiol sulphide contaminant and cyclohexene one olefin in fuels.

\section{EXPERIMENTAL}

\subsection{Preparation of adsorbent zeolitic $\mathrm{Ni} / \mathrm{NaY}$ by ion exchange}

The starting material for the preparation of the adsorbent with nickel was the $\mathrm{NaY}$ zeolite with molar silica to alumina ration of 5.6, provided by CENPES - PETROBRAS.

This study, adopted the best conditions for ion exchange, that is: temperature $70^{\circ} \mathrm{C}, \mathrm{pH}$ of $4.5-5.0$, ratio $\mathrm{Ni}^{2+} / \mathrm{Na}^{1+}$ of 1 , and a $5 \%$ percentage of incorporation of $\mathrm{Ni}$, obtained by Arroyo (1991).

In a flat-bottomed flask, $1000 \mathrm{~mL}$ of deionized water and $50 \mathrm{~g}$ of $\mathrm{NaY}$ zeolite were mixed under agitation, followed by the addition of $1000 \mathrm{~mL}(0.1$ $\mathrm{mol} \mathrm{L}^{-1}$ ) of nickel nitrate hexahydrate. The mixture remained under agitation for 2 hours, at $70^{\circ} \mathrm{C}$. During ion exchange, the $\mathrm{pH}$ was controlled using $\mathrm{HNO}_{3}$ at $6 \%$. At the end of the process, the mixture was vacuum-filtered and washed with distilled water at $28^{\circ} \mathrm{C}$. The material was placed in an oven to dry for 12 hours at $120^{\circ} \mathrm{C}$. Then, the material was calcined in a muffle with a ramp heating $4^{\circ} \mathrm{C}$ $\min ^{-1}$ until $550^{\circ} \mathrm{C}$. After the calcinations, the material was kept at this temperature for 1 hour and, then, transferred to desiccators. At that stage, the samples were separated for the direct pelletization and characterization.

\subsection{Pellet forming}

To obtain the pellets, graphite was used as a binding element to bring greater consistency and mechanical strength to the prepared material. In the experiment, $90 \mathrm{~g}$ of the adsorbent were mixed with $5 \%$ graphite, so that the latter would not interfere with the results of the adsorbent prepared. Then, the material was taken to make the pellets, forming pellets with approximately $1.2 \mathrm{~cm}$ diameter and $0.3 \mathrm{~cm}$ tall. The pellet was calcined at $550^{\circ} \mathrm{C}$ for 1 hour under the same conditions established in the ion exchange.

\subsection{Characterization of the $\mathrm{Ni} / \mathrm{NaY}$ adsorbent}

The identification of physical, chemical, and structural properties of the prepared adsorbent aims to characterize effects related to the activity of the material. The metal content of nickel in the material was quantified by atomic absorption 
spectrophotometry. Information on the crystallinity was obtained by X-ray diffraction. Thermal gravimetric analysis provided data on stability of the prepared material. Surface characteristics and volume of the porous structure were obtained from measurements of adsorption of inert gas.

\subsubsection{Chemical analysis - Atomic Absorption Spectrometry (AAS)}

Samples containing $1.00 \mathrm{~g}$ of $\mathrm{Ni} / \mathrm{NaY}$ adsorbent suffered successive chemical attacks using hydrochloric, hydrofluoric, and nitric acids that led to heating. Then, the samples were transferred to $250 \mathrm{~mL}$ flasks and measured with distilled water. Analyses were performed by a dual beam Varian Gemini 1475 model Atomic Absorption Spectrophotometer in an air-acetylene flame with a wavelength of $307.6 \mathrm{~nm}$.

\subsubsection{Textural characterization - nitrogen adsorption measurements}

The analyses for determination of the surface area were performed using a Quartachrome NOVA 2000 equipment. The experiment used about $300 \mathrm{mg}$ of sample and 5 seconds of time, with the objective of attaining surface area and pore volume of the sample. Subsequently, the sample was placed inside the vacuum chamber of the equipment under $300^{\circ} \mathrm{C}$ for 4 hours. Later, it was placed in a specimen holder which was immersed in a bath of liquid nitrogen at about $-95^{\circ} \mathrm{C}$. The equipment was programmed so that the measures were initiated after $120 \mathrm{~s}$ immersion in $\mathrm{N}_{2}$. This procedure aimed to eliminate the adsorbed water, some organic matter, or adsorbed gases present in the samples, which could influence the final results of the analysis.

\subsubsection{X-ray Diffraction (XRD)}

In this work, the analysis of X-ray diffraction, was performed by using a Siemens powder diffractometer model D5000, equipped with a $\mathrm{Cu}$ anode ( $\lambda \mathrm{Cu} \mathrm{K} \mathrm{K}_{\alpha}=1.5406 \mathrm{~A}$ ), and a monochromator, with programming appropriate to obtain interplanar distances and relative intensities. The voltage and current generators were adjusted to $40 \mathrm{kV}$ and $40 \mathrm{~mA}$, respectively, using a scanning range $(2 \theta)$ from $5^{\circ}$ to $100^{\circ}$, at a step of $0.02^{\circ}$ every second.

\subsubsection{Thermogravimetric analysis (TGA)}

The equipment used to perform the thermogravimetric analysis in this work was a microbalance THERMAL SCIENCES PL-STA model. The solid mass was $10 \mathrm{mg}$ being employed a heating rate of $10^{\circ} \mathrm{C} \mathrm{min}{ }^{-1}$ without gas flow. The sample was evenly distributed in the specimen holder and pre-treated at $450^{\circ} \mathrm{C}$, under flowing nitrogen for 3 hours. The analysis temperature ranged between $28^{\circ} \mathrm{C}$ and $1000^{\circ} \mathrm{C}$ and the gas flow in the treatment was of $25 \mathrm{~mL} \mathrm{~min}^{-1}$.

\subsection{Preparation of the propanethiol/cyclo- hexene mixture}

The experiment used sample fuel blends within the range of gasoline due to the complexity of working with the actual fuel. The composed mixture of propanethiol (representing the contaminant) and cyclohexene (representing hydrocarbons) was prepared in order to obtain a $1000 \mathrm{mg} \mathrm{L}^{-1}$ of sulfur concentration.

\subsection{Kinetic study}

A kinetic study was conducted with the pure adsorbent ( $\mathrm{NaY}$ ) and with the prepared adsorbent ( $\mathrm{Ni} / \mathrm{NaY})$, powdered and pelletized, using the finite bath method in a $250 \mathrm{~mL}$ Erlenmeyer flask containing $100 \mathrm{~mL}$ of a solution of $1000 \mathrm{mg} \mathrm{L}^{-1}$ sulfur and $10 \mathrm{~g}$ of adsorbent, which was kept under agitation for 24 hours at $28^{\circ} \mathrm{C}$.

Aliquots of $1.0 \mathrm{~mL}$ were taken at intervals of 1,5 , $10,15,30,60,120,240,360,600,800,1000$, and 1200 minutes. The fractions were filtered through Micropore filters and analyzed by gas chromatography to obtain the adsorbed amount of sulfur, in accordance with the time to evaluate the saturation time. The same study was done to solve propanethiol/cyclohexene, named white, in order to observe the existence of volatilization of the solution.

\subsection{Analysis of sulfur concentration}

The samples obtained from the sorption studies were analyzed in a Gas Chromatograph - Varian CP 3800 , with a coupled gun Front and flame ionization detector (FID). The following gases were admitted to the chromatograph: nitrogen as carrier gas and "make-up" gas and hydrogen and synthetic air as feed gas for the FID detector. The experiment 
Table 1. Programming the oven temperature.

\begin{tabular}{ccccc}
\hline Level & Temperature $\left({ }^{\circ} \mathbf{C}\right)$ & $\begin{array}{c}\text { Speed } \\
\left({ }^{\circ} \mathbf{C} \text { }^{-1}{ }^{-1}\right)\end{array}$ & $\begin{array}{c}\text { Time } \\
(\mathbf{m i n})\end{array}$ & $\begin{array}{c}\text { Total Time } \\
(\mathbf{m i n})\end{array}$ \\
\hline Initial & 40 & - & 4.50 & 4.50 \\
1 & 75 & 20 & 0.00 & 6.25 \\
2 & 250 & 50 & 1.25 & 11.00 \\
\hline
\end{tabular}

applied a dimethylpolysiloxane column $(30 \mathrm{~m}$ length $x$ internal diameter of $0.25 \mathrm{~mm} \times 0.25 \mathrm{~mm}$ film thickness) with a flow rate of $1 \mathrm{~mL} \mathrm{~min}^{-1}$ and ratio $1 / 100$, with typical analysis time of 10 minutes per sample and an injector temperature of $220^{\circ} \mathrm{C}$. Table 1 presents the temperature programming of the oven.

An external standard calculation for the quantification of results was used where its calibration curve had the following concentrations: $50,100,250,500,800,1250$, and $1000 \mathrm{mg} \mathrm{L}^{-1}(\mathrm{R}=$ $0.99895)$.

\section{RESULTS AND DISCUSSION}

\subsection{Characterization of the adsorbent}

\subsubsection{Chemical analysis - Atomic Absorption Spectrometry (AAS)}

Results of chemical analysis showed the incorporation of $5.4 \%$ nickel, percentage close to the theoretically estimated value (5\%). This result shows a very efficient ion exchange of sodium by nickel, justified by the size of the $\mathrm{Ni}^{2+}$ ion $(0.69 \AA)$ which was smaller than the $\mathrm{Na}^{+}$ion $(1.02 \AA)$, a trend accompanied by the respective hydrated ionic radii.

\subsubsection{Textural characterization - nitrogen Adsorption Measures}

The adsorption isotherms of $\mathrm{N}_{2}$ for the prepared $\mathrm{Ni} / \mathrm{NaY}$ adsorbent were of type I, characteristic of microporous solids. Table 2 presents the results of the adsorption of $\mathrm{N}_{2}$ for the prepared adsorbent. The results considers the same adsorbent after the step of pelletization as well as results obtained for a commercial adsorbent Selexsorb, from ALCOA and the NaY zeolite.

Analyzing the results in Table 2, one can observe that, with the incorporation of $5 \%$ nickel $\mathrm{NaY}$, there was an increase in BET surface area, in the micropore area and external surface area. This increase may have been caused by a possible disalumination of the zeolite, but also by the removal of silicates by nickel during ion exchange.

Table 2 shows that, although the incorporation of $\mathrm{Ni}$ in the zeolite $\mathrm{NaY}$ did not change the surface area, one can observe that the $\mathrm{Ni} / \mathrm{NaY}$ adsorbent in calcined and pelletized forms presented a greater external surface area when compared to the pure $\mathrm{NaY}$ zeolite. This difference indicates a generation of mesopores. However, for the pelletized $\mathrm{Ni} / \mathrm{NaY}$ adsorbent, there was a decrease in surface area and micropores. This reduction was caused probably by the agglomeration of the material during the pelletization and subsequent calcination, or the presence of $5 \%$ graphite.

Table 2. Results of the textural characterization of zeolitic adsorbent with Nickel, Selexsorb and NaY zeolite.

\begin{tabular}{ccccc}
\hline Adsorbent & $\begin{array}{c}\text { BET Surface } \\
\text { Area } \\
\left(\mathbf{m}^{\mathbf{2}} \mathbf{g}^{-1}\right)\end{array}$ & $\begin{array}{c}\text { Micropore } \\
\text { Area } \\
\left(\mathbf{m}^{2} \mathbf{~ g}^{-1}\right)\end{array}$ & $\begin{array}{c}\text { External } \\
\text { Surface Area } \\
\left(\mathbf{m}^{2} \mathbf{g}^{-1}\right)\end{array}$ & $\begin{array}{c}\text { Micropore } \\
\text { volume } \\
\left(\mathbf{c m}^{\mathbf{3}} \mathbf{g}^{-1}\right)\end{array}$ \\
\hline $\mathrm{NaY}$ & 518 & 514 & 4.6 & 0.29 \\
$\mathrm{Ni} / \mathrm{NaY}$ & 521 & 514 & 7.0 & 0.28 \\
$\mathrm{Ni} / \mathrm{NaY}$ Pellets & 390 & 379 & 11.6 & 0.20 \\
Selexsorb CDX & 431 & ---- & ---- & ---- \\
\hline
\end{tabular}

* Hoke et al., 2008. 


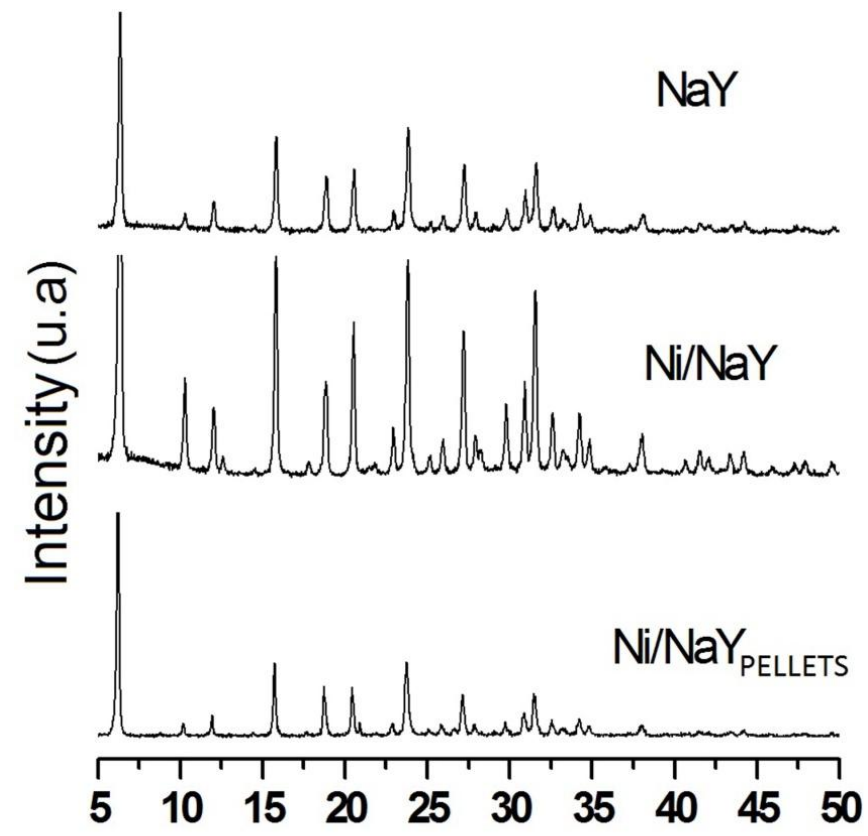

$2 \theta$

Figure 1. X-ray diffractogram of $\mathrm{NaY}$ zeolite and of the Ni/NaY adsorbent, pelletized and calcined $\left(550^{\circ} \mathrm{C} 1 \mathrm{~h}^{-1}\right)$.

\subsubsection{X-ray diffraction}

The $\mathrm{Ni} / \mathrm{NaY}$ adsorbent in calcined and in pellet forms was analyzed by X-ray diffraction to compare its crystalline state with the initial zeolite (pure $\mathrm{NaY}$ ). Figure 1 shows the $\mathrm{X}$-ray diffractogram of $\mathrm{NaY}$ zeolite used in the preparation of $\mathrm{Ni} / \mathrm{NaY}$ and diffraction patterns of the adsorbent $\mathrm{Ni} / \mathrm{NaY}$ in two forms, calcinated and in pellet. Characteristic peaks of $\mathrm{NaY}$ zeolite are observed characterizing it as a highly crystalline material.

Analyzing Figure 1, typical peaks of NaY zeolite are observed in the $\mathrm{Ni} / \mathrm{NaY}$ adsorbent in its two forms, calcinated and pelletized, showing that there was no change in the structure of this adsorbent.

The set of peaks observed at angles of $2 \theta=19$ 48 confirm the presence of nickel oxide, nickel aluminate $\left(\mathrm{NiAl}_{2} \mathrm{O}_{4}\right)$, and nickel silicate $\left(\mathrm{Ni}_{2} \mathrm{SiO}_{4}\right)$. The presence of nickel oxide as $\mathrm{Ni}_{2} \mathrm{O}_{3}$, in angles $2 \theta$ $=31.93$ and 44.83 , is evident. The presence of this oxide can possibly be justified by its position within and not on the surface of NaY zeolite, hindering its exit for transformation in the form of $\mathrm{NiO}$, which is stable at $550^{\circ} \mathrm{C}$.

For the pelletized $\mathrm{Ni} / \mathrm{NaY}$ adsorbent, the presence of such compounds are observed in general. The incorporation of $5 \%$ of graphite in the preparation of the pellet, influences the decrease of crystallinity, which can be confirmed by the decrease in intensity shown in Figure 1.

\subsubsection{Thermogravimetric analysis (TGA)}

Figure 2 shows the thermogravimetric curve for the $\mathrm{Ni} / \mathrm{NaY}$ adsorbent and shows an endothermic transformation of water loss between 30 and $180^{\circ} \mathrm{C}$. According to Breck (1984), this loss is relative to the water physically adsorbed in the zeolite and to the water lost in the hydration of the present cations.

The appearance of a second endothermic peak between $490-550^{\circ} \mathrm{C}$ can characterize the presence of $\mathrm{Ni}_{2} \mathrm{O}_{3}$, which did not undergo transformation into $\mathrm{NiO}$ at a temperature of $550^{\circ} \mathrm{C}$. This may have occurred by the position of this oxide within the zeolite in a place of difficult access.

\subsection{Kinetics of adsorption on sulfur removal}

The kinetic evolutions obtained during the experiments are shown in Figure 3. The experiments were carried out in accordance with the operating conditions described previously. 


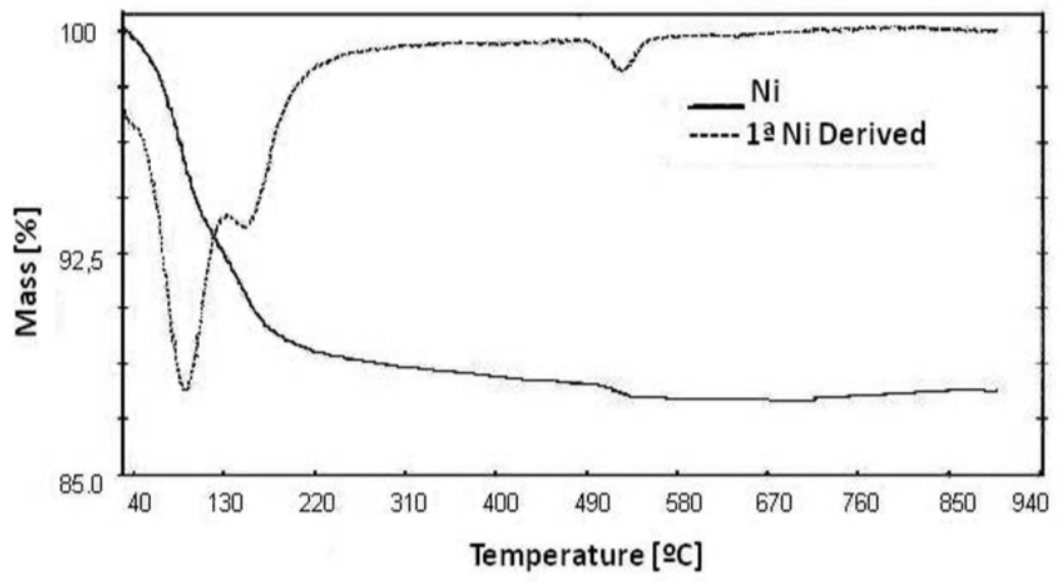

Figure 2. Curve of the thermogravimetric analysis of the $\mathrm{Ni} / \mathrm{NaY}$ adsorbent.

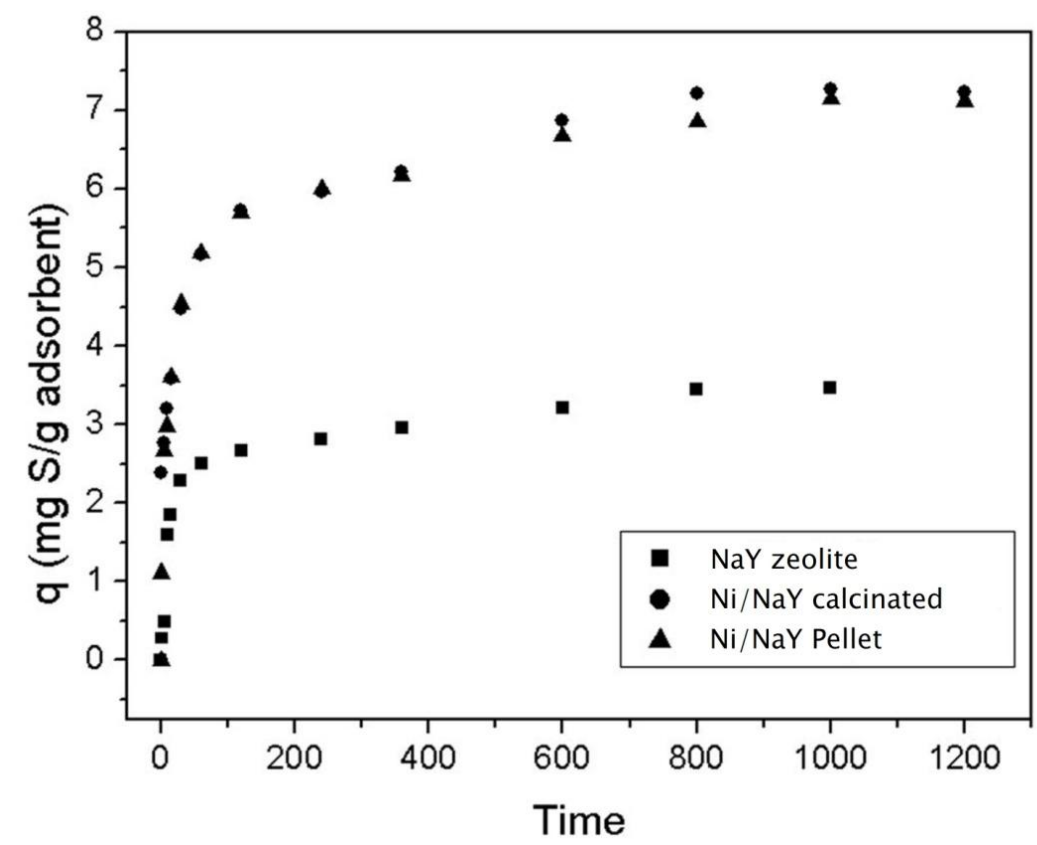

Figure 3. Kinetics of adsorption on the removal of propanethiol with $\mathrm{NaY}$ zeolite and $\mathrm{Ni} / \mathrm{NaY}$ adsorbent, in calcined and pelletized forms. Experimental conditions: $T=28^{\circ} \mathrm{C}, \mathrm{M}_{\mathrm{A}}=10 \mathrm{~g}, \mathrm{C}=1.000 \mathrm{mgL}^{-1}$.

Looking at Figure 3 one can observe an increased amount of sulfur adsorbed with time. It appears that the kinetics were very fast in the first minutes, reaching the bulk removal around 80 minutes. After 400 minutes, it occurs a balance in the system, and there is a lower adsorption capacity for $\mathrm{NaY}$ zeolite, with $\mathrm{q}_{\mathrm{NaY}}=3.46 \mathrm{mgS} \mathrm{g}^{-1}$ of adsorbent. For the adsorbent containing nickel, the adsorption capacities were respectively: $\mathrm{q}_{\mathrm{N} / \mathrm{NaY}}=$ $7.23 \mathrm{mgS} \mathrm{g}^{-1}$ of adsorbent and $\mathrm{q}_{\mathrm{Ni} / \mathrm{NaY} \text { pellet }}=7.12 \mathrm{mg}$ $\mathrm{g}^{-1}$ of adsorbent.

Similar results were obtained by Rios et al.
(2004), who observed an increase in capacity of elimination of propanethiol in hexene from 6 to 10 $\mathrm{mgS} \mathrm{g}^{-1}$ of adsorbent impregnated with 5 or $20 \%$ by weight of zinc oxide on charcoal.

\section{CONCLUSIONS}

The textural characterization showed that the volume of micropores of zeolitic adsorbent with calcined nickel (Ni/NaY) remained stable. There was an increase in the values of BET surface area 
and micropore area, with a decrease in the same values when pelletization of this material occurred.

Results obtained by X-ray diffraction showed the presence of aluminate and nickel silicate in the prepared adsorbent, which confirms the incorporation of metal to the zeolite structure.

The Ni/NaY adsorbent showed a better adsorption capacity in the removal of sulfur from the propanethiol/cyclohexene mixture than the $\mathrm{NaY}$, indicating the need to incorporate the nickel to the zeolitic support.

The kinetic evolution demonstrated that the incorporation of $\mathrm{Ni}$ into $\mathrm{NaY}$ zeolite provides a larger adsorptive capacity without significant differences between pelletized or not-pelletized form. Although the Ni/NaY adsorbent pellets had a smaller micropore volume and surface area (BET) when compared to the $\mathrm{Ni} / \mathrm{NaY}$ adsorbent, their adsorption capacities were similar. This indicates that the adsorption takes place preferentially on the external surface and the mesopore regions.

These results suggest that the process of impregnation of nickel oxide in $\mathrm{NaY}$ zeolite is a possible alternative in the adsorption of sulfur compounds.

\section{ACKNOWLEDGMENTS}

The present work was supported by PETROBRAS S.A., CAPES, FINEP, and MCT/CTPETRO.

\section{REFERENCES}

Arroyo, P. A. ; Souza-Aguiar, E. F. ; Monteiro, J. L. F. Influence of the zinc content on aromatics formation over zinc-containing ultra-stable $Y$ zeolites. Preprint of American Chemical Society, Div. of Petroleum Chemistry USA, New York, v. 36, n. 4, p. 685-692, 1991.

Bhandari, V. M.; Ko, C. H.; Park, J. G.; Han, S-S.; Cho, S-H.; Kim, J-N. Desulfurization of diesel using ion-exchanged zeolites. Chemical Engineering Science, v.61, p. 2599-2608, 2006. http://dx.doi.org/10.1016/i.ces.2005.11.015
Breck, D. W. Zeolite Molecular Sieves Structure, Chemistry and Use. Robert E. Publishing Co., 1984. p.1-18.

Breysse, M.; Mariadassou, G. D.; Pessayre, S.; Geantet, C.; Vrinat, M.; Pérot, G. Lemaire, M. Deep desulfurization: reactions, catalysts and technological challenges. Catalysis Today, v.84, p. 129-138. 2003. http://dx.doi.org/10.1016/S09205861(03)00266-9

Dauzacker, E. R.; Palombo, F. Boletim Técnico Petrobrás. Rio de Janeiro, v.46, p. 256-269, 2003.

Hoke, S., Hester, M., Ramji N. Flavor oils with reduced sulfur content and use in oral care compositions. US Patents 20080008667A1, Jan. 10, 2008, 18p.

King, D.; Faz, C.; Flynn, T. Desulfurization of Gasoline feedstocks for Application in Fuel reforming. Society of Automotive Engineers. SAE Technical Paper 2000-01-0002, 2000.

Li, F.; Song, L.; Duan, L.; Li, X.; Sun, Z. A frequency response study of thiophene adsorption in zeolite catalysts. Applied Surface Science, v.253, p. 8802-8809, 2007. http://dx.doi.org/10.1016/i.apsusc.2007.05.010

Li, X.; Zhang, X.; Lei, L. Preparation of CuNaY zeolites with microwave irradiation and their application for removing thiophene from model fuel. Separation and Purification Technology, v.64, p. 326-331, 2009.

http://dx.doi.org/10.1016/j.seppur.2008.10.016

Lin, L.; Zhang, Y.; Zhang, H.; Lu, F. Adsorption and solvent desorption behavior of ion-exchanged modified $Y$ zeolites for sulfur removal and for fuel cell applications Original Research Article. Journal of Colloid and Interface Science. v.360, p. 753-759, 2011. http://dx.doi.org/10.1016/j.jcis.2011.04.075

Nair, S.; Tatarchuk, B. J. Supported silver adsorbents for selective removal of sulfur species from hydrocarbon fuels, Fuel, v.89, p. 3218-3225, 2010. http://dx.doi.org/10.1016/i.fuel.2010.05.006

Noda, K.; Kogure, T.; Irisa, S.; Murakami, Y.; Sakata, M.; Kuroda, A. Enhanced dibenzothiophene biodesulfurization in a microchannel reactor. Biotechnology Letters. v.30, p. 451-454, 2008. http://dx.doi.org/10.1007/s10529-007-9557-5 
Oliveira, M. L. M.; Miranda, A. A. L.; Barbosa, C. M. B. M.; Cavalcante Jr., C. L.; Azevedo, D. C. S.; Rodriguez-Castellon, E. Adsorption of thiophene and toluene on $\mathrm{NaY}$ zeolites exchanged with $\mathrm{Ag}(\mathrm{I})$, $\mathrm{Ni}(\mathrm{II})$ and $\mathrm{Zn}(\mathrm{II})$. Fuel $\mathrm{L}_{2}$ v.88, p. 1885-1892. 2009. http://dx.doi.org/10.1016/i.fuel.2009.04.011

Rios, R .V. R. A.; Sepulvida-Escribano, A.; Rodriguez-Reinoso, F. Eliminación de azufre en nafta. In: Tecnologia Limpia para el aprovechamiento de olefinas ligeras, Ediciones CYTED, Porto, ISBN: 84-96023-28-1, p. 154-171, 2004.

Santos, A. L.; Reis, R. A.; Rossa, V.; Reis, M. M.; Costa, A. L. H.; Veloso, C. O.; Henriques, C. A.; Zotin, F. M. Z.; Paredes, M. L. L.; Silveira, E. B.; Chiaro, S. S. X. Silica-alumina impregnated with cerium, nickel, and molybdenum oxides for adsorption of sulfur and nitrogen compounds from diesel. Materials Letters. v.83, p. 158-160, 2012. http://dx.doi.org/10.1016/j.matlet.2012.06.011

Song, C. An overview of new approaches to deep desulfurization for ultra-clean gasoline, diesel fuel and jet fuel. Catalysis Today, v.86, p. 211-263, 2003.

http://dx.doi.org/10.1016/S0920-5861(03)00412-7
Song, C.; Ma, X. New design approaches to ultra-clean diesel fuels by deep desulfurization and deep dearomatization. Applied Catalysis B: Environmental, v.41, p. 207-238, 2003. http://dx.doi.org/10.1016/S0926-3373(02)00212-6

Takahashi, A.; Yang, F. H.; Yang, R. T. New Sorbents for Desulfurization by $\pi$ Complexation:Thiophene/Benzene Adsorption. Industrial \& Engineering Chemistry Research. v.41, p. 2487-2496, 2002.

http://dx.doi.org/10.1021/ie0109657

Velu, S.; Ma, X.; Song, C. Selective adsorption for removing sulfur from jet fuel over zeolite-based adsorbents. Industrial \& Engineering Chemistry Research, v.42, p. 5293-5304, 2003. http://dx.doi.org/10.1021/ie020995p 